Fetal Diagnosis and Therapy
Fetal Diagn Ther 2011;29:274-279

DOI: $\underline{10.1159 / 000323327}$
Received: November 1, 2010

Accepted after revision: November 22, 2010

Published online: February 3, 2011

\title{
Maternal Serum Adiponectin at 11-13 Weeks of Gestation in Pregnancies Delivering Small for Gestation Neonates
}

\author{
Surabhi Nanda ${ }^{a}$ Ranjit Akolekar $^{a}$ Danielle Sodre ${ }^{a}$ birini Vaikousi ${ }^{a, b}$ \\ Kypros H. Nicolaides ${ }^{a, b}$ \\ a Harris Birthright Research Centre for Fetal Medicine, King's College Hospital, and b Fetal Medicine Unit, \\ University College Hospital, London, UK
}

\section{Key Words}

Adiponectin • Pregnancy-associated plasma protein A •

First trimester $\cdot$ Small for gestational age $\cdot$ Fetal growth restriction

\section{Abstract \\ Objective: To investigate whether maternal serum levels of adiponectin in the first trimester are altered in pregnancies that subsequently deliver small for gestational age (SGA) ne- onates. Methods: Maternal serum adiponectin and preg- nancy-associated plasma protein A (PAPP-A) were measured at 11-13 weeks' gestation in 50 singleton normotensive pregnancies that delivered SGA neonates and 300 non-SGA controls. The median adiponectin and PAPP-A levels in the SGA and non-SGA groups, expressed as multiple of the unaf- fected median (MoM), were compared. Results: The distribu- tion of serum adiponectin was made gaussian by square root (sqrt) transformation. Regression analysis in the non-SGA group demonstrated that for sqrt adiponectin a significant independent contribution was provided by maternal age, weight, smoking status, African and South-Asian racial ori- gin. Each value in the SGA and non-SGA group was then con- verted into a multiple of the non-SGA median (MoM) after}

adjustment for maternal characteristics. In the SGA group, compared to the non-SGA controls, median maternal serum PAPP-A was decreased $(0.79$, interquartile range [IQR] $0.54-$ 1.06 MoM vs. 1.00, IQR 0.71-1.39 MoM) but adiponectin MoM was not significantly different (0.89, IQR $0.65-1.31$ MoM vs. 1.02, IQR 0.70-1.29 MoM). Conclusion: Maternal serum adiponectin is not a useful biochemical marker for early prediction of SGA.

Copyright $\odot 2011$ S. Karger AG, Basel

\section{Introduction}

Adiponectin, an adipocyte-derived protein, is thought to play an important role in the regulation of insulin resistance, atherosclerosis and inflammatory responses and angiogenesis $[1,2]$. Serum adiponectin concentration is inversely correlated with insulin resistance and is consequently reduced in obesity and type 2 diabetes mellitus $[3,4]$. Adiponectin may also play a role in fetal growth, probably by enhancing the growth-promoting effect of insulin through its insulin-sensitizing action [5]. In small for gestational age (SGA) pregnancies there is reduced placental content and maternal serum or plasma concen- 
tration of adiponectin [6, 7]. Additionally, adiponectin levels are reduced in cord blood of SGA neonates and in the blood of children that were SGA at birth $[8,9]$.

The aim of this study is to investigate whether the low maternal serum level of adiponectin observed in association with SGA fetuses precedes the onset of the fetal growth deficiency and is apparent from the first trimester of pregnancy. In addition, we investigate whether the serum level of adiponectin is related to alterations in placental function, reflected in the serum level of PAPP-A, which is known to be decreased in affected pregnancies [10].

\section{Methods}

\section{Study Population}

This was a case-control study drawn from a large prospective observational study for early prediction of pregnancy complications in women attending for their routine first hospital visit in pregnancy at King's College Hospital, London, UK. In this visit, which is held between $11^{+0}$ and $13^{+6}$ weeks of gestation, we record maternal characteristics and medical history, and perform combined screening for aneuploidies by measurement of the fetal crown-rump length (CRL) and nuchal translucency thickness and maternal serum PAPP-A and free $\beta$-hCG $[11,12]$. We stored serum and plasma at $-80^{\circ} \mathrm{C}$ for subsequent biochemical analysis from women agreeing to participate in the study. Written informed consent was obtained for the study, which was approved by King's College Hospital ethics committee.

In this study we measured maternal serum adiponectin in 50 cases that subsequently delivered SGA neonates in the absence of preeclampsia because we have previously reported that in this condition the levels are increased [13]. The levels were compared to 300 non-SGA controls who delivered a phenotypically normal neonate at term. Cases and controls were selected at random from our database of stored samples. None of the samples in this study were previously thawed and refrozen.

\section{Outcome Measures}

Data on pregnancy outcome were obtained from the maternity computerised records or the general medical practitioners of the women and were recorded in our database. The neonate was considered to be SGA if the birth weight was less than the $3 \mathrm{rd}$ percentile for gestation at delivery, using a reference range derived from our population [10]. Neonates with birth weight at or above the 5 th percentile were classified as non-SGA.

\section{Sample Analysis}

A duplicate serum sample of $250 \mu \mathrm{l}$ was used to measure adiponectin concentration by a quantitative enzyme-linked immunoassay (ELISA) technique using Quantikine Adiponectin ELISA kit (DRP300; R\&D Systems Europe Ltd., Abingdon, UK). The lower limit of detection of the assay was $0.246 \mathrm{ng} / \mathrm{ml}$ and the between-batch coefficient of variation $(\mathrm{CV})$ was $6.8 \%$ at an adiponectin concentration of $20.5 \mathrm{ng} / \mathrm{ml}, 5.8 \%$ at $74.4 \mathrm{ng} / \mathrm{ml}$ and $6.9 \%$ at $10.8 \mathrm{ng} / \mathrm{ml}$. All samples were analyzed in duplicate and those with a CV exceeding $10 \%$ were re-analyzed.

Adiponectin and Small for Gestation
Literature Search

We searched Medline and Embase from January 1995, when adiponectin was first described, to September 2010 to identify studies reporting on the relationship between SGA neonates and adiponectin concentration in the plasma or serum of the mother, neonate or child.

\section{Statistical Analysis}

The distribution of serum adiponectin was made gaussian by square root (sqrt) transformation and normality was confirmed using Kolmogorov-Smirnov test $(\mathrm{D}=0.03, \mathrm{p}=0.20)$. In the group of 300 non-SGA controls, multiple regression analysis was used to determine which of the factors amongst the maternal characteristics and gestation provided a significant contribution in predicting sqrt adiponectin [14]. Each value in the SGA and non-SGA group was then converted into a multiple of the non-SGA median (MoM) after adjustment for those characteristics found to be significant in the multiple regression analysis. Similarly, the distribution of PAPP-A was made gaussian after logarithmic transformation and each value in the SGA and non-SGA group was then converted in a MoM after adjustment for gestation, maternal age, racial origin, maternal weight, smoking, parity, and method of conception as previously described [15]. Mann-Whitney U test was used to compare median MoM values of adiponectin and PAPP-A between the outcome groups. Regression analysis was used to determine the significance of association between maternal serum adiponectin and PAPP-A in the SGA and non-SGA groups.

The statistical software package SPSS 16.0 (SPSS Inc., Chicago, Ill., USA) was used for data analyses.

\section{Results}

The maternal characteristics of the SGA and non-SGA groups are compared in table 1 . In the SGA group the median maternal weight was lower, more women delivered SGA neonates in their previous pregnancies and more required assisted conception techniques.

Multiple regression analysis in the non-SGA group demonstrated that for sqrt adiponectin significant independent contribution was provided by maternal age, weight, smoking status, African and South-Asian racial origin but not by fetal CRL ( $\mathrm{p}=0.459)$, method of conception $(\mathrm{p}=0.637)$ or parity $(\mathrm{p}=0.219)$ : sqrt adiponectin expected $=130.19+0.74 \times$ maternal age in years + $(-18.24$ if the racial origin was African, -31.89 if South Asian, 0 if Caucasian, East Asian or Mixed) $-0.53 \times$ maternal weight in $\mathrm{kg}-10.38$ if cigarette smoker; $\mathrm{R}^{2}=0.223$, $\mathrm{p}<0.0001$.

In the SGA group, compared to the non-SGA controls, median maternal serum PAPP-A MoM was decreased but adiponectin MoM was not significantly different (table 2; fig. 1). There was no significant association of sqrt adiponectin MoM with birth weight percentile in either the 
Table 1. Maternal and pregnancy characteristics in the outcome groups

\begin{tabular}{lcc}
\hline Maternal characteristics & $\begin{array}{l}\text { Unaffected controls } \\
(\mathrm{n}=300)\end{array}$ & $\begin{array}{l}\text { Small for gestation } \\
(\mathrm{n}=50)\end{array}$ \\
\hline Median maternal age, years (IQR) & $32.2(26.9-35.6)$ & $30.5(26.5-35.9)$ \\
Median maternal weight, kg (IQR) & $63.3(57.0-70.0)$ & $59.3(52.0-68.3)^{*}$ \\
Median crown-rump length, mm (IQR) & $64.0(58.7-69.6)$ & $62.1(55.3-66.5)$ \\
Median gestation at sampling, weeks (IQR) & $12.4(12.1-12.9)$ & $12.4(12.1-12.6)$ \\
Racial origin, n (\%) & $189(63.0)$ & $24(48.0)$ \\
$\quad$ Caucasian & $86(28.7)$ & $17(34.0)$ \\
$\quad$ African & $10(3.3)$ & $4(8.0)$ \\
South Asian & $6(2.0)$ & $3(6.0)$ \\
$\quad$ East Asian & $9(3.0)$ & $2(4.0)$ \\
$\quad$ Mixed & $148(49.3)$ & $28(56.0)$ \\
Parity, n (\%) & $140(46.7)$ & $12(24.0)^{*}$ \\
$\quad$ Nulliparous & $12(4.0)$ & $10(20.0)^{*}$ \\
$\quad$ Parous - no previous SGA & $28(9.3)$ & $9(18.0)$ \\
$\quad$ Parous - SGA & & $46(92.0)$ \\
Cigarette smoker, n (\%) & $4(8.0)^{*}$ \\
Conception, n (\%) & $296(98.7)$ & $1.3(0.4-2.0)^{*}$ \\
Spontaneous & $4(1.3)$ & $39.0(38.1-40.0)^{*}$ \\
$\quad$ Assisted & $50.5(32.6-68.7)$ & \\
Median birth weight percentile (IQR) & $40.1(39.2-41.0)$ & \\
Median gestation at delivery, weeks (IQR) & & \\
\hline
\end{tabular}

Comparisons between outcome groups ( $\chi^{2}$ test and Fisher's exact test for categorical variables and MannWhitney $\mathrm{U}$ test for continuous variables). ${ }^{*} \mathrm{p}<0.05 . \mathrm{IQR}=$ Interquartile range.

Table 2. MoM (IQR) for maternal serum adiponectin and PAPP-A in the outcome groups

\begin{tabular}{lcc}
\hline Variable & $\begin{array}{l}\text { Unaffected controls } \\
(\mathrm{n}=300)\end{array}$ & $\begin{array}{l}\text { Small for gestation } \\
(\mathrm{n}=50)\end{array}$ \\
\hline $\begin{array}{c}\text { Adiponectin } \\
\mathrm{ng} / \mathrm{ml}\end{array}$ & $\begin{array}{c}12,035(8,595-17,085) \\
\mathrm{MoM}\end{array}$ & $\begin{array}{c}11,373(8,193-14,938) \\
0.89(0.65-1.31)\end{array}$ \\
$\begin{array}{c}\mathrm{PAPP}-\mathrm{A} \\
\mathrm{mIU} / \mathrm{ml}\end{array}$ & $3.07(2.03-4.76)$ & $2.21(1.50-4.08)$ \\
$\mathrm{MoM}$ & $1.00(0.71-1.39)$ & $0.79(0.54-1.06)^{*}$ \\
\hline
\end{tabular}

Comparisons between outcome groups by Mann-Whitney U test. Significance level ${ }^{*} \mathrm{p}<0.05$.

SGA group ( $\mathrm{p}=0.335)$ or the non-SGA group $(\mathrm{p}=0.558)$. Similarly, there was no significant association of sqrt adiponectin MoM with gestation at delivery in the SGA group $(p=0.070)$. There was a significant association of sqrt adiponectin MoM with $\log _{10}$ PAPP-A MoM in the SGA group $(\mathrm{r}=0.344, \mathrm{p}=0.014)$ but not in the non-SGA group $(\mathrm{p}=0.094)$.

\section{Literature Search}

The literature search identified 15 studies reporting on the association between serum or plasma adiponectin concentration and SGA neonates in pregnancy, the neonatal period and early childhood. In some of the studies, adiponectin was measured by radioimmunoassay (RIA) but in most studies an ELISA technique was used. The birth weight cut-off for definition of SGA was the 10th, 5 th or the 3rd centile. The levels of adiponectin in the SGA group were lower than in the non-SGA group in about half of the studies and there were no significant differences in the other half (table 3).

\section{Discussion}

The findings of this study confirm that in pregnancies delivering SGA neonates there is evidence of impaired placentation reflected in reduced maternal serum concentration of PAPP-A at 11-13 weeks' gestation. In contrast, the maternal serum adiponectin levels in pregnancies that subsequently deliver SGA neonates are not significantly different from pregnancies with normal fetal growth. 
Fig. 1. Maternal serum adiponectin and PAPP-A, expressed as multiple of the normal median (MoM), at 11-13 weeks' gestation plotted against fetal CRL in pregnancies delivering SGA neonates $(\bullet)$ and nonSGA neonates $(\bigcirc)$.
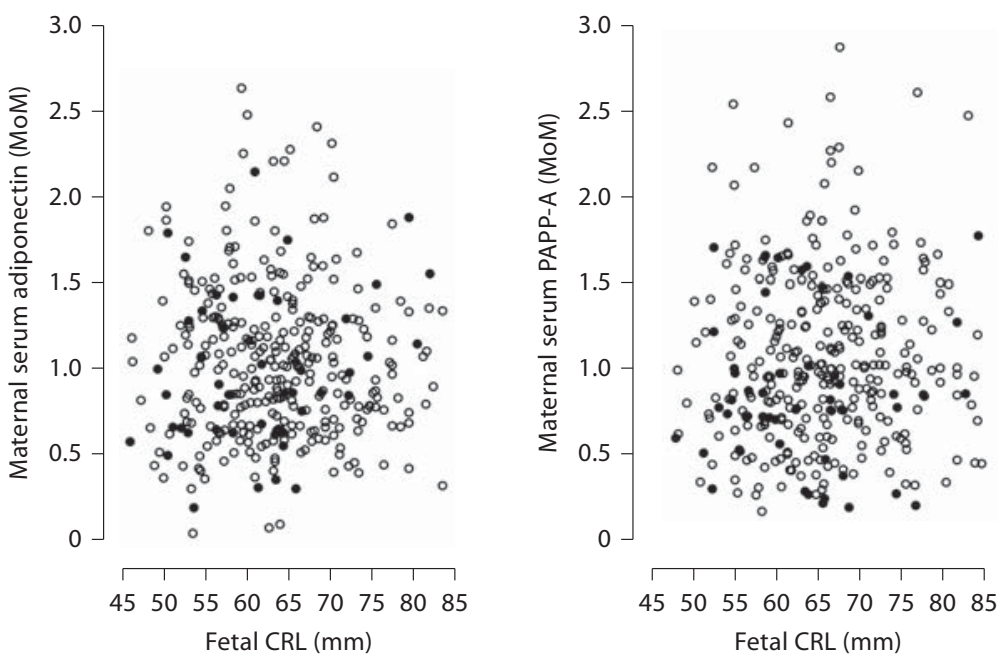

Table 3. Studies reporting on the association between SGA and serum or plasma adiponectin concentration (mean or median) in the mother, neonate or child

\begin{tabular}{|c|c|c|c|c|c|c|c|c|}
\hline \multirow[t]{2}{*}{ Reference (first author) } & \multirow[t]{2}{*}{ Assay } & \multirow[t]{2}{*}{$\begin{array}{l}\text { Time point } \\
\text { of evaluation }\end{array}$} & \multicolumn{2}{|c|}{$\begin{array}{l}\text { Small for } \\
\text { gestational age }\end{array}$} & \multicolumn{2}{|c|}{$\begin{array}{l}\text { Appropriate for } \\
\text { gestational age }\end{array}$} & \multirow[t]{2}{*}{$\mathrm{p}$} & \multirow[t]{2}{*}{$\begin{array}{l}\text { SGA } \\
\text { definition }\end{array}$} \\
\hline & & & $\mathrm{n}$ & $\begin{array}{l}\text { Adiponectin } \\
\mu \mathrm{g} / \mathrm{ml}\end{array}$ & $\mathrm{n}$ & $\begin{array}{l}\text { Adiponectin } \\
\mu \mathrm{g} / \mathrm{ml}\end{array}$ & & \\
\hline \multicolumn{9}{|l|}{ During pregnancy } \\
\hline Fasshauer, 2007 [17] & ELISA & $33-41 \mathrm{WG}$ & 6 & 6.5 & 10 & 7.7 & NS & $<5$ th centile \\
\hline Kyriakakou, 2008 [7] & RIA & $36-40 \mathrm{WG}$ & 20 & 5.4 & 20 & 11.8 & $<0.05$ & $<3$ rd centile \\
\hline Meral, $2010[20]$ & ELISA & $36-41 \mathrm{WG}$ & 20 & 0.81 & 20 & 1.51 & $<0.05$ & $<10$ th centile \\
\hline \multicolumn{9}{|l|}{ Neonatal period } \\
\hline Kamoda, $2004[8]$ & RIA & cord blood & 28 & 23.2 & 34 & 33.2 & 0.02 & $<2.5$ th centile \\
\hline Martínez-Cordero, 2006 [21] & RIA & cord blood & 50 & 29.7 & 50 & 23.5 & NS & $<2,500 \mathrm{~g}$ \\
\hline Takaya, 2007 [22] & ELISA & cord blood & 20 & 11.4 & 45 & 17.1 & $<0.005$ & $<5$ th centile \\
\hline Meral, 2010 [20] & ELISA & $1-4$ days & 20 & 2.6 & 20 & 6.7 & $<0.05$ & $<10$ th centile \\
\hline \multicolumn{9}{|l|}{ Childhood } \\
\hline Cianfarani, 2004 [9] & RIA & $5-14$ years & 51 & 35.2 & 24 & 77.5 & $<0.0001$ & $<3$ rd centile \\
\hline López-Bermejo, 2004 [24] & ELISA & $3-9$ years & 32 & 18.7 & 37 & 14.5 & $<0.0001$ & $<10$ th centile \\
\hline Evagelidou, 2007 [25] & ELISA & $6-8$ years & 20 & 14.3 & 35 & 10.8 & $<0.05$ & $<10$ th centile \\
\hline Sancakli, 2008 [26] & RIA & $5-7$ years & 24 & 20.5 & 62 & 21.6 & NS & $<2.5$ th centile \\
\hline
\end{tabular}


In normal pregnancy, maternal serum adiponectin concentration increases with maternal age, decreases with weight and is lower in women of African and SouthAsian racial origin and in cigarette smokers. Within the narrow gestational range of 11-13 weeks there was no significant association between maternal serum adiponectin and fetal CRL. A previous longitudinal study of 11 normal pregnancies reported that maternal serum adiponectin levels were inversely related to body mass index and increased between 7 and 17 weeks, decreasing thereafter until term [16]. Consequently, in the comparison between the SGA and non-SGA groups, the appropriate adjustments were made for these maternal characteristics.

Previous studies examining adiponectin levels in the mothers, neonates and children from SGA pregnancies reported that the levels were lower or not significantly different from non-SGA pregnancies [7-9, 17-26]. Similarly, studies investigating the relation between adiponectin levels and birth weight in healthy pregnancies have found contradictory results with some reporting a positive correlation [27-31] and others no significant association [32, 33]. These conflicting results may be the consequence of methodological differences between studies, including assay techniques, definitions of SGA and differences in study populations, because most of these studies did not adjust the measured levels for maternal characteristics.

The reduced adiponectin levels in association with poor fetal growth, observed in some of the studies, may reflect the suggested role of this protein in the regulation of angiogenesis, the inflammatory response and insulin resistance. In previous studies, we reported that at 11-13 weeks the maternal serum adiponectin concentration is increased in pregnancies that subsequently develop preeclampsia and decreased in pregnancies that develop gestational diabetes mellitus $[13,14]$. The possible association between reduced adiponectin levels and impaired fetal growth is compatible with the findings that SGA neonates are more likely to develop the metabolic syndrome [34] and children born SGA exhibit altered body composition with increased visceral adiposity [35].

Impaired fetal growth is associated with increased risk of perinatal death and handicap. Early estimation of patient-specific risks for SGA could potentially improve pregnancy outcome by shifting antenatal care from a series of routine visits to a more individualised approach both in terms of the schedule and content of such visits [36]. These risks of perinatal death and handicap are substantially reduced in cases of SGA identified antenatally, compared to those detected after birth [37]. Additionally, there is evidence that the prophylactic use of low-dose aspirin started in early pregnancy can potentially halve the incidence of SGA [38]. We have previously reported that the use of an algorithm combining maternal characteristics and a series of biophysical and biochemical markers at 11-13 weeks could potentially identify, at a false positive rate of $10 \%$, about $75 \%$ of pregnancies without preeclampsia delivering SGA neonates before 37 weeks and $45 \%$ of those delivering at term [39]. Our finding of no significant differences in maternal serum adiponectin levels at 11-13 weeks' gestation between the SGA and non-SGA groups implies that the altered maternal levels do not precede the onset of fetal growth deficiency and therefore, measurement of maternal serum adiponectin in the first trimester is unlikely to contribute in the early prediction of fetal growth restriction.

\section{Acknowledgements}

The study was supported by a grant from The Fetal Medicine Foundation (UK Charity No. 1037116). The assay for adiponectin was performed by Ms. Tracy Dew at the Department of Biochemistry, King's College Hospital, London, UK.
References adipose-specific protein, adiponectin in obesity. Biochem Biophys Res Commun 1999;257:79-83.

G, Lodish HF: A novel serum protein simila to $\mathrm{Clq}$, produced exclusively in adipocytes. J Biol Chem 1995;270:26746-26749.

2 Mazaki-Tovi S, Kanety H, Sivan E: Adiponectin and human pregnancy. Curr Diab Rep 2005;5:278-281.

3 Arita Y, Kihara S, Ouchi N, Takahashi M, Maeda K, Miyagawa J Hotta K, Shimomura I, Nakamura T, Miyaoka K, Kuriyama H, Nishida M, Yamashita S, Okubo K, Matsubara K, Muraguchi M, Ohmoto Y, Funahashi T, Matsuzawa Y: Paradoxical decrease of an
4 Hotta K, Funahashi T, Arita Y, Takahashi M, Matsuda M, Okamoto Y, Iwahashi $\mathrm{H}, \mathrm{Ku}$ riyama $\mathrm{H}$, Ouchi $\mathrm{N}$, Maeda $\mathrm{K}$, Nishida $\mathrm{M}$, Kihara S, Sakai N, Nakajima T, Hasegawa K, Muraguchi M, Ohmoto Y, Nakamura T, Yamashita S, Hanafusa T, Matsuzawa Y: Plasma concentrations of a novel, adiposespecific protein, adiponectin, in type 2 diabetic patients. Arterioscler Thromb Vasc Biol 2000;20:1595-1599. 
5 Briana DD, Malamitsi-Puchner A: The role of adipocytokines in fetal growth. Ann NY Acad Sci 2010;1205:82-87.

-6 Street ME, Volta C, Ziveri MA, Viani I, Bernasconi S: Markers of insulin sensitivity in placentas and cord serum of intrauterine growth-restricted newborns. Clin Endocrinol 2009;71:394-399.

7 Kyriakakou M, Malamitsi-Puchner A, Militsi H, Boutsikou T, Margeli A, Hassiakos D, Kanaka-Gantenbein C, Papassotiriou I, Mastorakos G: Leptin and adiponectin concentrations in intrauterine growth restricted and appropriate for gestational age fetuses, neonates, and their mothers. Eur J Endocrinol 2008; 158:343-348.

$\checkmark 8$ Kamoda T, Saitoh H, Saito M, Sugiura M, Matsui A: Serum adiponectin concentrations in newborn infants in early postnatal life. Pediatr Res 2004;56:690-693.

-9 Cianfarani S, Martinez C, Maiorana A, Scirè G, Spadoni GL, Boemi S: Adiponectin levels are reduced in children born small for gestational age and are inversely related to postnatal catch-up growth. J Clin Endocrinol Metab 2004;89:1346-1351.

- 10 Poon LC, Karagiannis G, Staboulidou I, Shafiei A, Nicolaides KH: Reference range of birth weight with gestation and first-trimester prediction of small-for-gestation neonates. Prenat Diagn 2011;31:58-65.

- 11 Snijders RJ, Noble P, Sebire N, Souka A, Nicolaides KH: UK multicentre project on assessment of risk of trisomy 21 by maternal age and fetal nuchal-translucency thickness at 10-14 weeks of gestation. Lancet 1998;352: 343-346.

$\checkmark 12$ Kagan KO, Wright D, Baker A, Sahota D, Nicolaides KH: Screening for trisomy 21 by maternal age, fetal nuchal translucency thickness, free $\beta$-human chorionic gonadotropin, and pregnancy-associated plasma protein-A. Ultrasound Obstet Gynecol 2008; 31:618-624.

13 Nanda S, Yu CKH, Giurcaneanu L, Akolekar $\mathrm{R}$, Nicolaides KH: Maternal serum adiponectin at 11-13 weeks of gestation in preeclampsia. Fetal Diagn Ther DOI: 10.1159/000322402.

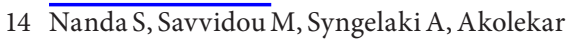
R, Nicolaides KH: Prediction of gestational diabetes mellitus by maternal factors and biomarkers at 11-13 weeks. Prenat Diagn DOI:10.1002/pd.2636.

15 Kagan KO, Wright D, Spencer K, Molina FS, Nicolaides KH: First-trimester screening for trisomy 21 by free $\beta$-human chorionic gonadotropin and pregnancy-associated plasma protein-A: impact of maternal and pregnancy characteristics. Ultrasound Obstet Gynecol 2008;31:493-502.

-16 Fuglsang J, Skjaerbaek C, Frystyk J, Flyvbjerg A, Ovesen P: A longitudinal study of serum adiponectin during normal pregnancy. BJOG 2006;113:110-113.
7 Fasshauer M, Bluher M, Stumvoll M, Tonessen P, Faber R, Stepan H: Differential regulation of visfatin and adiponectin in pregnancies with normal and abnormal placental function. Clin Endocrinol 2007;66:434-439. 18 Savvidou MD, Sotiriadis A, Kaihura C, Nicolaides KH, Sattar N: Circulating levels of adiponectin and leptin at 23-25 weeks of pregnancy in women with impaired placentation and in those with established fetal growth restriction. Clin Sci (Lond) 2008;115: 219-224.

19 Mazaki-Tovi S, Romero R, Vaisbuch E, Erez O, Mittal P, Chaiworapongsa T, Kim SK, Pacora P, Yeo L, Gotsch F, Dong Z, Yoon BH, Hassan SS, Kusanovic JP: Maternal serum adiponectin multimers in patients with a small-for-gestational-age newborn. J Perinat Med 2009;37:623-635.

20 Meral C, Cekmez F, Pirgon O, Asya Tanju I, Metin Ipcioglu O, Karademir F, Gocmen I: The relationship between serum visfatin, adiponectin, and insulin sensitivity markers in neonates after birth. J Matern Fetal Neonatal Med 2011;24:166-170.

-21 Martínez-Cordero C, Amador-Licona N, Guízar-Mendoza JM, Hernández-Méndez J, Ruelas-Orozco G: Body fat at birth and cord blood levels of insulin, adiponectin, leptin, and insulin-like growth factor-I in smallfor-gestational-age infants. Arch Med Res 2006;37:490-494.

22 Takaya J, Yamato F, Higashino H, Kaneko K: Intracellular magnesium and adipokines in umbilical cord plasma and infant birth size. Pediatr Res 2007;62:700-703.

-23 Ibáñez L, Sebastiani G, López-Bermejo A, Díaz M, Gómez-Roig MD, de Zegher F: Gender specificity of body adiposity and circulating adiponectin, visfatin, insulin, and insulin growth factor-I at term birth: relation to prenatal growth. J Clin Endocrinol Metab 2008;93:2774-2778.

-24 López-Bermejo A, Casano-Sancho P, Fernández-Real JM, Kihara S, Funahashi T, Rodríguez-Hierro F, Ricart W, Ibañez L: Both intrauterine growth restriction and postnatal growth influence childhood serum concentrations of adiponectin. Clin Endocrinol (Oxf) 2004;61:339-346.

25 Evagelidou EN, Giapros VI, Challa AS, Kiortsis DN, Tsatsoulis AA, Andronikou SK: Serum adiponectin levels, insulin resistance, and lipid profile in children born small for gestational age are affected by the severity of growth retardation at birth. Eur J Endocrinol 2007;156:271-277.

26 Sancakli O, Darendeliler F, Bas F, Gokcay G, Disci R, Aki S, Eskiyurt N: Insulin, adiponectin, IGFBP-1 levels and body composition in small for gestational age born nonobese children during prepubertal ages. Clin Endocrinol (Oxf) 2008;69:88-92.
27 Pardo IM, Geloneze B, Tambascia MA, Barros-Filho AA: Hyperadiponectinemia in newborns: relationship with leptin levels and birth weight. Obes Res 2004;12:521-524.

28 Sivan E, Mazaki-Tovi S, Pariente C, Efraty Y, Schiff E, Hemi R, Kanety H: Adiponectin in human cord blood: relation to fetal birth weight and gender. Clin Endocrinol Metab 2003;88:5656-5660.

29 Kotani Y, Yokota I, Kitamura S, Matsuda J, Naito E, Kuroda Y: Plasma adiponectin levels in newborns are higher than those in adults and positively correlated with birth weight. Clin Endocrinol (Oxf) 2004;61:418423.

30 Tsai PJ, Yu CH, Hsu SP, Lee YH, Chiou CH, Hsu YW, Ho SC, Chu CH: Cord plasma concentrations of adiponectin and leptin in healthy term neonates: positive correlation with birthweight and neonatal adiposity. Clin Endocrinol (Oxf) 2004;61:88-93.

- 31 Inami I, Okada T, Fujita H, Makimoto M, Hosono S, Minato M, Takahashi S, Harada $\mathrm{K}$, Yamamoto T: Impact of serum adiponectin concentration on birth size and early postnatal growth. Pediatr Res 2007;61:604606.

32 Verhaeghe J, van Bree R, Van Herck E: Maternal body size and birth weight: can insulin or adipokines do better? Metabolism 2006; 55:339-344.

33 Ong GK, Hamilton JK, Sermer M, Connelly PW, Maguire G, Zinman B, Hanley AJ, Retnakaran R: Maternal serum adiponectin and infant birthweight: the role of adiponectin isoform distribution. Clin Endocrinol (Oxf) 2007;67:108-114.

34 Lévy-Marchal C, Czernichow P: Small for gestational age and the metabolic syndrome: which mechanism is suggested by epidemiological and clinical studies? Horm Res 2006 65:123-130.

-35 Varvarigou AA: Intrauterine growth restriction as a potential risk factor for disease onset in adulthood. J Pediatr Endocrinol Metab 2010;23:215-224.

36 Nicolaides KH: Turning the pyramid of prenatal care. Fetal Diagn Ther 2011 (in press).

37 Lindqvist PG, Molin J: Does antenatal identification of small-for-gestational age fetuses significantly improve their outcome? Ultrasound Obstet Gynecol 2005;25:258-264.

38 Bujold E, Roberge S, Lacasse Y, Bureau M, Audibert F, Marcoux S, Forest JC, Giguère Y: Prevention of preeclampsia and intrauterine growth restriction with aspirin started in early pregnancy. A meta-analysis. Obstet Gynecol 2010;116:402-414.

39 Karagiannis G, Akolekar R, Sarquis R, Wright D, Nicolaides KH: Prediction of small for gestation neonates from biophysical and biochemical markers at 11-13 weeks. Fetal Diagn Ther DOI:10.1159/000321694. 